\title{
PENGARUH STRATEGI PEMBELAJARAN BERBASIS MASALAH DAN INTERAKSI SOSIAL TERHADAP HASIL BELAJAR SEJARAH SISWA SMA NEGERI 1 PADANG TUALANG KABUPATEN LANGKAT
}

\author{
Muhammad Nuh ${ }^{1}$, Sahat Siagian ${ }^{2}$ \\ Pascasarjana Universitas Negeri medan ${ }^{1,2}$ \\ wildanoeh@yahoo.co.id,
}

\begin{abstract}
Abstrak: Penelitian ini bertujuan untuk : (1) mengetahui perbedaan hasil belajar siswa yang diajar dengan strategi pembelajaran berbasis masalah dan strategi pembelajaran ekspositori, (2) mengetahui perbedaan hasil belajar Sejarah antara siswa yang memiliki interaksi sosial kompetitif dan interaksi sosial koperatif, (3) mengetahui interaksi antara strategi pembelajaran dan interaksi sosial dalam mempengaruhi hasil belajar Sejarah siswa. Metode penelitian quasi eksperimen dengan Anava 2 jalur yang sebelumnya, terlebih dahulu dilakukan uji persyaratan analisis data yaitu uji normalitas dengan uji Lilliefors dan uji homogenitas varians dengan uji Bartlett dan Uji Fisher. Hasil pengujian hipotesis menunjukkan bahwa: (1) hasil belajar Sejarah siswa yang dibelajarkan dengan strategi pembelajaran berbasis masalah lebih tinggi dibandingkan dengan siswa yang dibelajarkan dengan strategi pembelajaran ekspositori; (2) siswa yang memiliki interaksi sosial kompetitif memperoleh hasil belajar Sejarah yang lebih tinggi dibandingkan dengan siswa yang memiliki interaksi sosial koperatif, dan (3) terdapat interaksi antara strategi pembelajaran dan interaksi sosial dalam mempengaruhi hasil belajar Sejarah siswa.
\end{abstract}

Kata Kunci: strategi pembelajaran berbasis masalah, interaksi social, hasil belajar sejarah

\begin{abstract}
This study aimed to: (1) determine differences in learning outcomes of students who are taught by a strategy problem-based learning and learning strategies expository, (2) determine differences in learning outcomes history between students who have social interaction competitive and social interaction co-operative, (3) the interaction between the learning strategies and social interaction in influencing student learning outcomes History. Quasi experimental research methods with Anova 2 previous track, first tested the data analysis requirements that normality test test test Lilliefors and homogeneity of variance with Bartlett's test and Fisher test. Hypothesis testing results show that: (1) The history of student learning outcomes that learned with problem-based learning strategy is higher than students that learned with expository teaching strategy; (2) students who have gained a competitive social interaction learning outcomes Historical higher than students who have social interaction co-operative, and (3) there is no interaction between the learning strategies and social interaction in influencing student learning outcomes History.
\end{abstract}

Keywords: strategy of problem-based learning, social interaction, learning outcomes history

\section{PENDAHULUAN}

Berkaitan dengan proses pembelajaran Sejarah di sekolah, guru sangat berperan dalam menentukan berhasil tidaknya tujuan pembelajaran. Idealnya dalam merancang kegiatan pembelajaran, guru harus dapat melatih siswa untuk bertanya, mengamati, menyelidiki, membaca, mencari dan menemukan jawaban atas pertanyaan baik yang diajukan oleh guru maupun yang mereka ajukan sendiri. Pengetahuan yang disampaikan kepada siswa bukan hanya dalam bentuk produk, tetapi juga dalam bentuk proses, artinya dalam proses mengajar, pengenalan, pemahaman, pelatihan metode, dan penalaran siswa, mempakan hal yang penting untuk diajarkan (Atmadi, 2000).

Kenyataanya dalam proses pembelajaran Sejarah yang telah dilaksanakan selama ini, guru beranggapan bahwa proses dan isi mata pelajaran tidak begitu penting. Dalam mengajar guru memiliki otoritas tunggal, dan yang paling mencolok adalah minimnya aktivitas yang mendorong siswa untuk berefleksi dan berafeksi, untuk mengembangkan pemikiran kritis (critical thinking), pemikiran yang reflektif (reflective thinking), daya afektif, dan 
daya kreatif yang menjadi motor penggerak aktivitas hidup yang positif, produktif, dan konstruktif (Atmadi, 2000). Akibatnya mata pelajaran Sejarah dianggap membosankan karena sebahagian besar siswa harus mengahafal, tanpa ada masalah yang dihadapi (Somantri, 2001).

Oleh karena itu, perlu diadakan pengkajian dan inovasi dalam strategi pembelajaran berbasis masalah. Strategi pembelajaran berbasis masalah memberikan kebebasan kepada siswa dalam belajar, dan mereka didorong belajar secara mandiri dalam mengolah informasi. Dengan demikian, mereka sebagai makhluk yang unik, dalam arti memiliki perbedaan satu sama lain diakui sepenuhnya. Pengakuan demikian membangkitkan kegairahan siswa dalam belajar, karena mereka merasa dihargai, dipercaya, dan diberi kesempatan untuk menunjukkan kemampuan (Sanjaya, 2007). Selanjutnya, Kirchenbaum dalam Davies (1994), menunjukkan, apabila anak didik dilibatkan dalam proses pembelajaran maka sikap apatis, menolak, dan tingkah laku yang menyimpang akan berkurang, sebaliknya akan menimbulkan kegairahan belajar dan membuat anak didik berpikir secara lebih kritis. Situasi seperti ini diduga akan merangsang siswa untuk mengeluarkan seluruh potensi yang ada pada dirinya lebih baik.

Selain pemilihan strategi pembelajaran yang tepat, perolehan hasil belajar suatu kegiatan pembelajaran juga dipengaruhi oleh kemampuan guru dalam mengenal dan memahami karakteristik siswa. Seorang guru yang mampu mengetahui karakteristik siswa akan dapat membantu terselenggaranya proses pembelajaran secara efektif. Menurut Bruner dalam Hermanto (1979), proses pembelajaran dikatakan efektif apabila terjadi transfer belajar, yaitu materi pelajaran yang disajikan oleh guru dapat diserap oleh struktur kognitif siswa. Siswa dapat menguasai materi tersebut tidak hanya terbatas pada tahap ingatan tanpa pengertian (rote learning), tetapi diserap secara bermakna (meaningful learning). Agar terjadi transfer belajar yang efektif, maka guru harus memperhatikan karakteristik setiap siswa untuk dapat disesuaikan dengan materi yang dipelajarinya. Rogers (1982) mengatakan bahwa pembelajaran akan semakin efektif atau semakin berkualitas bila proses pembelajaran dilakukan sesuai dengan karakteristik siswa yang diajar. Sejalan dengan hal tersebut, Slavin dan Hamachek (1990) mengemukakan bahwa karakteristik adalah aspek-aspek yang ada dalam diri siswa yang dapat mempengaruhi perilakunya. Selanjutnya, menurut Dick \& Carey (2006), seorang guru hendaknya mampu untuk mengenal dan mengetahui karakteristik siswa, sebab pemahaman yang baik terhadap karakteristik siswa akan sangat berpengaruh terhadap keberhasilan proses belajar siswa. Apabila seorang guru telah mengetahui karakteristik peserta didiknya, maka selanjutnya guru dapat menyesuaikan strategi, strategi atau teknik pembelajaran yang sesuai dengan karakteristik siswa tersebut.

Belajar adalah suatu perubahan watak (disposition) dan kemampuan (capability) manusia yang berlangsung selama suatu jangka waktu dan tak sekedar menganggapnya proses pertumbuhan (Romizowski, 1981). Selanjutnya, Romizowski mengatakan bahwa belajar terjadi apabila suatu situasi stimulus bersama dengan isi ingatan mempengaruhi siswa sedemikian rupa sehingga perbuatan (performance) berubah dari waktu ke waktu selama ia mengalami situasi. Sedangkan Gagne (1977) menjelaskan, belajar adalah suatu proses yang kompleks dan hasil belajar merupakan kemampuan yang disebabkan oleh : (1) stimulus yang berasal dari lingkungan, dan (2) proses kognisi yang dilakukan oleh siswa/siswi, setelah siswa memiliki keterampilan, pengetahuan, sikap dan nilai. Belajar terjadi bila ada hasilnya yang dapat diperlihatkan, dan belajar merupakan proses perubahan tingkah laku, yaitu perolehan ilmu pengetahuan dan teknologi yang sebelumnya seseorang belum memilikinya. Perolehan yang dimaksud banyak tergantung pada bagaimana proses belajar dapat berlangsung secara efektif.

Gerlach dan Ely (1980) memberikan definisi belajar sebagai perubahan perilaku yang relatif permanen. Belajar sebagai proses di mana tingkah laku akan diubah melalui latihan atau pengalaman. Dengan demikian, perubahan perubahan tingkah laku akibat pertumbuhan fisik atau kematangan, kelelahan, penyakit atau pengaruh obat-obatan adalah tidak termasuk belajar.

Menurut pandangan Behavioristek seperti Weaston, Thorndike, Skinner dalam Dimyati dan Mudjiono (1994), belajar adalah perubahan tingkahlaku. Yang dimaksud tingkahlaku di sini adalah tingkahlaku yang dapat diamati. Belajar merupakan proses dasar dari perkembangan hidup manusia, dengan belajar manusia 
melakukan perubahan-perubahan pada dirinya sehingga tigkahlaku berkembang. Sedangkan menurut pandangan kognitif seperti : Piaget, Glaser, Anderson, Brunner dan Ausebel belajar adalah proses internal yang tidak dapat secara langsung. Dari kedua pandangan tersebut di atas dapat disimpulkan bahwa guru pasti dihadapkan pada tingkahlaku siswa yang dapat diamati seperti hasil kerja siswa dan tingkahlaku siswa yang tidak dapat diamati seperti perasaan, pengetahuan dan sikap.

Dari pengertian Sejarah dapat diketahui bahwa di dalam sejarah terkandung beberapa aspek yang perlu dipelajari, yaitu aspek pengetahuan, aspek sikap, dan aspek ketrampilan. Aspek-aspek ini perlu dipelajari dalam proses belajar-mengajar di sekolah. Hal ini akan bermanfaat bagi peserta didik dalam upaya memecahkan permasalahan yang dihadapi di dalam masyarakat pada masa yang akan datang. Sering dikatakan bahwa pelajaran sejarah penting artinya bagi kehidupan manusia, yaitu sebagai tambahan pengalaman, upaya untuk menjaga peninggalan masa lampau, mengetahui pertentangan antar suku bangsa yang mungkin mempunyai permasalahan yang sama. Oleh karena belajar sejarah mempunyai tujuan yang baik bagi generasi muda. Tujuan mempelajari sejarah adalah agar supaya kita menjadi bijaksana lebih dulu (Soewarso, 2000).

Reigeluth (1989) mengatakan bahwa hasil belajar secara umum dapat dikategorikan menjadi tiga indikator, yaitu : (1) efektivitas pembelajaran yang biasanya diukur dari tingkat keberhasilan siswa dari berbagai sudut, (2) efisiensi pembelajaran, yang biasanya diukur dari waktu belajar atau biaya pembelajaran, dan (3) daya tarik pembelajaran yang selalu diukur dari tendensasi siswa ingin belajar secara terus menerus. Secara sfesifflc hasil belajar adalah suatu kenerja atau performance yang diindikasikan suatu kapabilitas (kemampuan) yang diperoleh. Menurut Snelbecker (1874) bahwa ciri-ciri tingkah laku yang diperoleh dari hasil belajar adalah : (1) terbentuknya tingkah laku baru berupa aktual maupun potensial, (2) kemampuan itu berlaku dalam waktu yang relatiflama, dan (3) kemampuan baru itu diperoleh melalui usaha.

Secara umum strategi mempunyai pengertian suatu garis-garis haluan untuk berindak dalam usaha mencapai sasaran yang telah ditemukan. Dihubungkan dengan belajar mengajar, strategi bisa diartikan sebagai pola- pola umum kegiatan guru-anak didik dalam perwujudan kegiatan belajar mengajar untuk mencapai tujuan yang telah digariskan. Heinich (1996) berpendapat bahwa pembelajaran merupakan susunan dari pada informasi lingkungan yang memudahkan belajar. Melalui lingkungan setiap siswa tidak hanya memerlukan metode, media dan perlengkapan lain untuk menyampaikan informasi, dan membimbing dirinya untuk belajar. Dengan demikian pembelajaran dapat diartikan sebagai usaha yang dilakukan secara sengaja dengan menggunakan metode, media daftar perlengkapan lainnya, sehingga siswa memperoleh kemudahan dalam mempelajari materi. Kondisi pembelajran ini terlaksana berdasarkan strategi pembelajaran tertentu.

Selain itu Dick dan Carey (2006) menyatakan bahwa strategi pembelajaran menjelaskan komponen-komponen umum dari suatu set bahan pengajaran dan prosedurprosedur yang akan digunakan untuk menghasilkan belajar tertentu pada siswa. Strategi pembelajaran berkenaan dengan pendekatan pengajaran dalam mengelola kegiatan pembelajaran untuk menyampaikan materi secara sistematik sehingga kemampuan yang diharapkan dapat dikuasai oleh siswa secara efektif dan efisien. Dalam strategi pembelajaran terkandung empat pengertian yakni: 1) urutan kegiatan pembelajaran, yaitu urutan kegiatan pengajar dalam menyampaikan isi pelajaran kepada siswa; 2) metode pembelajaran, yaitu cara pengajar mengorgamsasikan materi pembelajaran dan siswaan agar terjadi proses belajar secara efektif dan efisien; 3) media pembelajaran, yaitu peralatan dan bahan pembelajaran yang digunakan pengajar dan siswa dalam kegiatan pembelajaran; 4) waktu yang digunakan oleh pengajar dan siswa dalam menyelesaikan setiap langkah dalam kegiatan siswa (Suparman, 1997).

terhadap anak didik dan penciptaan kondisi belajar murid secara aktif. Selanjutnya Romizowski (1981) mengemukakan bahwa setiap strategi pembelajaran yang dikembangkan selalu mencerminkan posisi teoritis yang dianut, tentang bagaimana seharusnya pembelajaran itu dilaksanakan. Hamalik (1993) mendefinisikan strategi belajarmengajar sebagai system menyeluruh yang terdiri dan sejumlah komponen, yaitu komponen masukan (input), komponen proses dan komponen produk (output). Strategi 
pembelajaran dalam rangka pengembangan kognitif dan aktivitas anak didik, merupakan hal terpenting yang harus diperhatikan. Bila strategi pembelajaran dapat membangkitkan atau mendorong timbulnya aktivitas anak didik, maka proses belajar merekapun akan lebih banyak terlaksana dan dengan demikian hasil belajamya akan lebih baik. Selanjutnya, Gagne dan Briggs (1974) menyebutkan strategi pembelajaran sebagai serangkaian kegiatan yang dirancang untuk memungkinkan terjadinya proses belajar pada siswa. Sesuai dengan rumusan pengertian yang dikemukakan di atas, dapat dinyatakan bahwa ada empat karakteristik yang harus dimiliki oleh setiap strategi pembelajaran, yaitu: (1) berorientasi pada tujuan, (2) kondisi, (3) sistematik, dan (4) evaluasi dan revisi.

Strategi pembelajaran berbasis masalah adalah strategi pembelajaran yang memberikan kesempatan kepada siswa untuk menetapkan topik masalah, walaupun sebenarnya guru sudah mempersiapkan apa yang harus dibahas. Proses pembelajaran diarahkan agar siswa mampu menyelesaikan masalah secara sistematis dan logis (Sanjaya, 2007). Dalam strategi pembelajaran ini siswa akan menemukan sendiri permasalahan dan mencari sendiri solusi atas permasalahan yang mereka munculkan tersebut, sehingga siswa memperoleh pengalaman tersendiri dalam rangka memecahkan sebuah masalah. Pentingnya keterlibatan mental dalam belajar telah dibuktikan oleh Salomon dalam Djahiri (1980) bahwa besarnya koefisien korelasi antara prestasi belajar dengan kemampuan umum, dapat dijadikan sebagai indikasi tentang besarnya investasi usaha mental seseorang dalam belajar, semakin besar keterlibatan mental dalam belajar maka kian besar pula koefisien korelasinya terhadap prestasi belajar.

Dengan menerapkan kegiatan
menemukan apa yang menjadi kebutuhan belajarnya, siswa diharapkan akan lebih mampu mengenal dan menggambarkan kapasitas belajar dan potensi yang dimilikinya secara penuh, menyadari dan dapat menggunakan potensi sumber belajar yang terdapat di sekitarnya. Selama belajar siswa menggunakan potensi sumber belajar yang terdapat di sekitarnya. Selama belajar siswa diharapkan lebih banyak untuk berprakarsa, berpikir secara teratur, kritis, tanggap dan dapat memecahkan masalah. Dazies dalam Sanjaya (2007) menyatakan bahwa hal apapun yang dipelajari siswa, maka ia harus mempelajari sendiri, tidak ada seorangpun dapat melakukan kegiatan belajar tersebut untuknya. Pernyataan tersebut secara mutlak menuntut adanya keterlibatan langsung dari setiap siswa dalam kegiatan belajar. Implikasi prinsip ini dituntut pada para siswa agar tidak segan-segan mengerjakan segala tugas belajar yang akan diberikan kepada mereka. Dengan keterlibatan langsung ini secara logis akan menyebabkan mereka memperoleh pengalaman.

Strategi pembelajaran berbasis masalah dapat dikatakan bertujuan untuk membiasakan siswa melakukan keterampilan proses dalam menemukan ilmu pengetahuan. Keterampilan proses sangat tepat diterapkan dalam pengajaran. Semiawan (2002), mengemukakan bahwa ada beberapa alasan memilih pendekatan keterampilan proses dalam pengajaran, yaitu (1) pengetahuan berkembang terus sehingga guru tidak mungkin mengajarkan semua fakta dan konsep kepada siswa, (2) anak didik mudah memahami konsep rumit dan abstrak kalau disertaii kondisi dan situasi dalam upaya menanamkan konsep melalui perlakuan terhadap fisik dan pengamatan, (3) penemuan tidak benar seratus persen atau suatu teori dapat berubah dengan ditemukannya teori baru, dan (4) tujuan pembelajaran mengembangkan konsep tidak terlepas dari pengembangan nilai dan norma dalam diri anak. Sedangkan dalam GBPP mata pelajaran Sejarah (Depdiknas, 1993), dinyatakan bahwa metode mengajar sedapat mungkin dapat melayani perbedaan kebutuhan individual siswa, dan dalam proses pembelajaran guru bahkan satu-satunya sumber belajar, oleh karena itu perlu upaya untuk mengoptimalkan pemanfaatan sumber-sumber belajar yang tersedia oleh siswa.

Dalam mengelola kelas ada pandangan yang sifat otoritatif yaitu kelas sebagai proses untuk mengontrol tingkah laku siswa dan sebaliknya ada pandangan yang bersifat permisif, yaitu menekankan bahwa tugas guru adalah memaksimalkan perwujudan kebebasan siswa. Sikap yang permisif ini membiarkan anak berkembang dalam kebebasan tanpa banyak tekanan, larangan, perintah atau paksaan (Nasution, 2003). Lebih lanjut dikemukakan bahwa memecahkan masalah dapat dipandang sebagai proses di mana pelajar menemukan kombinasi aturan-aturan yang telah dipelajarinya lebih dahulu yang digunakan untuk memecahkan masalah baru. Dalam pemecahan masalah yang mencakup 
keterampilan intelektual, siswa menghasilkan ketentuan-ketentuan yang relevan dari yang dipelajari sebelumnya. Berdasarkan uraian yang dikemukakan dapat disimpulkan bahwa dalam pemecahan masalah siswa terlibat dalam belajar penemuan (discovery learning) dan dalam pemecahan masalah prosesnya terutama terletak dalam diri siswa sendiri. Siswa harus didorong untuk memecahkan masalah dalam kerja kelompok atau perseorangan. Guru merupakan nara sumber yang tugasnya memberikan bantuan yang diperlukan untuk menjamin bahwa siswa tidak menjadi frustasi atau gagal.

Dewey dalam Hamalik (1993), menyatakan bahwa pembelajaran berbasis masalah dilakukan dengan langkah-langkah sebagai berikut: (1) merumuskan masalah, yaitu langkah siswa menetukan masalah yang akan dipecahkan, (2) menganalisis masalah, yakni langkah siswa meninjau masalah secara kritis dari berbagai sudut pandang, (3) merumuskan hipotesis, yakni langkah siswa merumuskan berbagai kemungkinan pemecahan masalah sesuai dengan pengetahuan yang dimilikinya, (4) mengumpulkan data, yaitu langkah siswa mencari dan menggambarkan informasi yang diperlukan untuk pemecahan masalah, (5) pengujian hipotesis, yakni langkah siswa mengambil atau merumuskan kesimpulan sesuai dengan penerimaan dan penolakan hipotesis yang diajukan, dan (6) merumuskan rekomendasi pemecahan masalah, yakni langkah siswa menggambarkan rekomendasi yang dapat dilakukan sesuai rumusan hasil pengujian hipotesis dan rumusan kesimpulan.

Sanjaya (2007) mengemukakan bahwa keunggulan strategi pembelajaran berbasis masalah di antaranya: (a) pemecahan masalah (problem solving) merupakan teknik yang cukup bagus untuk lebih memahami isi pelajaran, dan (b) pemecahan masalah dapat menantang kemampuan siswa serta memberikan kepuasan untuk menemukan pengetahuan baru bagi siswa, (c) pemecahan masalah dapat meningkatkan aktivitas pembelajaran siswa, (d) pemecahan masalah dapat membantu siswa bagaimana mentransfer pengetahuan mereka untuk memahami masalah dalam kehidupan nyata, (e) pemecahan masalah dapat membantu siswa untuk mengembangkan pengetahuan barunya dan bertanggung jawab dalam pemebelajaran yang mereka lakukan, dan (f) melalui pemecahan masalah bisa memperlihatkan kepada siswa bahwa setiap mata pelajaran pada dasarnya merupakan cara berpikri, dan sesuatu yang barus dimengerti oleh siswa, bukan hanya sekedar belajar dari guru atau dari buku-buku saja.

Dari pendapat di atas jelas bahwa guru sebagai penentuan dan pengarah untuk membimbing siswa selangkah demi selangkah supaya siswa dapat belajar bekerja sendiri untuk mencapai prosedur pemecahan masalah dan menemukan sendiri jawabannya. Hal ini sesuai dengan yang dikemukakan oleh Merrill (1981) bahwa bagian-bagian pembelajaran itu berupa petunjuk untuk siswa mengenai bagaimana strategi dapat memproses informasi yang dipresentasikan. Dalam strategi pembelajaran berbasis masalah dengan bimbingan ini guru kurang aktif mempresentasikan bagian-bagian pengajarannya.

Strategi pembelajaran ekspositori adalah strategi pembelajaran yang menekankan kepada proses penyampaian materi secara verbal dari seorang guru kepada sekelompok siswa dengan maksud agar siswa dapat menguasai materi pembelajaran secara optimal. Killen dalam Sanjaya (2007) menamakan strategi ekspositori ini dengan istilah strategi pembelajaran langsung (direct insruction), karena dalam strategi ini materi pembelajaran disampaikan langsung oleh guru, dan siswa tidak dituntut untuk menemukan sendiri materi itu, dan materi pembelajaran seakan-akan sudah jadi atau telah dipersiapkan oleh guru.

Strategi pembelajaran ekspositori akan efektif apabila : (a) guru akan menyampaikan bahan-bahan baru serta kaitannya dengan yang akan dan harus dipelajari siswa (overview). Biasanya bahan atau materi baru itu diperlukan untuk kegiatan-kegiatan khusus, seperti kegiatan pemecahan masalah atau untuk melakukan proses tertentu. Oleh sebab itu, materi yang disampaikan adalah materi-materi dasar seperti konsep-konsep tertentu, prosedur atau rangkaian aktivitas, dan lain sebagainya, (b) apabila guru menginginkan agar siswa mempunyai gaya model intelektual tertentu, misalnya agar siswa bisa mengingat bahan pelajaran sehingga ia akan dapat mengungkapkannya kembali apabila diperlukan, (c) jika bahan pelajaran yang akan diajarkan cocok untuk dipresentasikan, artinya dipandang dari sifat dan jenis materi pembelajaran, memang materi pembelajaran itu hanya mungkin dapat dipahami oleh siswa apabila disampaikan oleh guru, misalnya materi pembelajaran hasil penelitian berupa data-data khusus, (d) jika ingin membangkitkan 
keingintahuan siswa tentang topik tertentu. Misalnya, materi pembelajaran yang bersifat pancingan untuk meningkatkan motivasi belajar siswa, (e) guru menginginkan untuk mendemonstrasikan suatu teknik atau prosedur tertentu untuk kegiatan praktik. Prosedur tersebut biasanya merupakan langkah baku atau langkah standard yang harus ditaati dalam melakukan suatu proses tertentu. Apabila langkah itu tidak ditaati, maka dapat menimbulkan pengaruh atau resiko tertentu, (f) apabila seluruh siswa memiliki tingkat kesulitan yang sama, sehingga guru perlu menjelaskan untuk seluruh siswa, (g) apabila guru akan mengajar pada sekolompok siswa yang rata-rata memiliki kemampuan rendah. Berdasarkan hasil penelitian Ross \& Kyle dalam Sanjaya (2007), strategi ini sangat efektif untuk mengajarkan konsep dan keterampilan untuk anak-anak yang memiliki kemampuan kurang (low achieving students), (h) jika lingkungan tidak mendukung untuk menggunakan strategi yang berpusat pada siswa, misalnya tidak adanya sarana dan prasarana yang dibutuhkan, dan (i) jika guru tidak memiliki waktu yang cukup untuk menggunakan pendekatan yang berpusat pada siswa.

Sebagai makhluk sosial, manusia dalam kehidupannya membutuhkan hubungan dengan manusia lainnya. Kecenderungan manusia untuk berhubungan melahirkan komunikasi dua arah yang mengandung tindakan dan perbuatan. Karena ada aksi dan reaksi maka interaksi sosialpun terjadi. Walgito (2002) mengemukakan bahwa interaksi sosial ialah hubungan antara individu satu dengn individu lain, individu satu dapat mempengaruhi individu yang lain atau sebaliknya, jadi terdapat adanya hubungan timbal balik di mana hubungan tersebut dapat antar individu dengan individu, individu dengan kelompok atau kelompok dengan kelompok.

Interaksi sosial timbul karena manusia sebagai makhluk sosial di samping juga sebagai makhluk individual. Dikatakan sebagai makhluk individu manusia mempunyai dorongan atau motif untuk mengadakan hubungan dengan dirinya sendiri, sedangkan sebagai makhluk sosial manusia mempunyai dorongan untuk mengadakan hubungan dengan orang lain. Dengan adanya dorongan atau motif sosial pada manusia, maka manusia akan mencari orang lain untuk mengadakan hubungan atau mengadakan interaksi (Walgito, 2002).
Hubert Bonner seperti yang dikutip oleh Arifin (2000) memberikan pendapat bahwa interaksi sosial merupakan suatu bentuk hubungan antara dua orang atau lebih di mana tingkahlaku seseorang dirubah oleh tingah laku orang lain. Melalui dorongan antar pribadi dan respon tersebut seseorang yang bersifat biologis lamban laun berubah menjadi makhluk hidup atau pribadi. Proses interaksi sosial tersebut berlangsung secara timbal balik di mana masing-masing betindak dalam keseluruhan proses yang mempengaruhi atau menyebabkan yang juga bertindak. Interaksi sosial yang demikian merupakan perilaku timbal balik, suatu perilaku di mana masing-masing individu dalam proses itu mengharapkan dan menyesuaikan diri dengan tindakan yang akan dilakukan orang lain.

Berkaitan dengan proses interaksi sosial, Newcomb, Turner, dan Converse (1985) menjelaskan bahwa interaksi sosial terjadi melalui proses : (1) komunikasi yaitu bentuk hubungan interpersonal di mana orang dapat mengadakan kontak dengan isi pikiran orang lain; (2) norma-norma yaitu penerimaan seserang atau sekelompok orang terhadap suatu peraturan; (3) respon interpersonal yaitu hubungan timbal balik seseorang atau sekelompok orang yang saling pengaruh mempengaruhi dengan jalan yang sama. Proses interaksi tersebut membntuk hubungan yang dinamis antara individu yang satu dengan individu yang lain.

Proses interaksi merupakan tindakan saling pengaruh mempengaruhi antara individu yang satu dengan individu lainnya, sehingga timbul kemungkinan-kemungkinan untuk saling mengubah atau memperbaiki perilaku masingmasing secara timbal balik. Perubahan demikian bisa terjadi secara disadari atau tidak disadari atau tidak sepenuhnya disadari, secara spontan atau secara perlahan-lahan. Hal ini terjadi juga dalam kegiatan pemelajaran yang di dalamnya terdapat interaksi antara guru dan siswa. Proses interaksi sosial antara guru dan siswa menjadi permulaan yang fundamental bagi suksesnya pembelajaran sebab proses belajar mengajar merupakan proses kegiatan interaksi atara dua unsur manusiawi yaitu siswa sebagai si pemelajar dan guru sebagai pembelajaran (Sardiman, 2003). Interaksi sosial yang terjadi dalam pembelajaran trsebut merupakan interksi sosial di dalam kelompok belajar di mana tiap siswa sebagai anggota kelompok saling tergantung satu sama lainnya, 
dan setidak-tidaknya mereka memiliki petensi untuk melakukan interaksi sosial satu sama lain (Newcomb, Turner dan Converse, 1985). Berkaitan dengan tingkahlaku siswa sebagai individu yang berinteraksi dalam kelompoknya, Kuhlman dan Wimberley seperti yang dikutip oleh Sears, Fredman dan Peplau (1999) mengklarifikasikan tiga tipe tingkah laku individu dalam berinteraksi sosial dengan kelompoknya yang diuraikan sebagai berikut: (1) pekerjan (coperator) adalah tingkahlaku yang mementingkan pemaksimalan ganjaran yang diterimanya maupun yang diterima temannya; (2) pesaing (competitor) adalah tingkahlaku yang berorientasi pada pemaksimalan hasilnya sendiri agar lebih banyak dari hasil temannya; (3) individualis adalah tingkahlaku yang mengutamakan pemaksimalan hasilnya sendiri tanpa memperdulikan kekalahan atau kemenangan temannya. Lebih lanjut Sears, Fredman dan Peplau menjelaskan dari ketiga tingkahlaku tersebut, dalam berinteraksi dalam kelompoknya individu cenderung akan membentuk interaksi secara: (a) bekerjasama atau koperatif di mana mereka saling menolong satu sama lain, berbagi informasi, bekerja sama untuk mendapatkan keuntungan bersama yang intinya adalah tingkahlaku yang saling memperindah ditimbulkan oleh kesadaran akan sesuatu nasib yang diingin oleh semua anggota kelompok; (b) bersaing atau kompetitif di mana mereka mengutamakan tujuan sendiri dan berusaha menyisihkan yang lainnya dan ditandai oleh tingkahlaku yang saling bertentangan karena nasib mereka di dalam kelompok dianggap bertentangan.

Bentuk interaksi sosial koperatif sangat berlawanan dengan interaksi sosial secara kompetitif. Newcomb, Turner dan Converse (1985) menjelaskan bahwa ciri-ciri interaksi sosial secara koperatif terdiri dari : (1) konsensus rasa memiliki bersama yaitu adanya penerimaan bersama terhadap aturan-aturan atau keadaan-keadaan normative yang menyangkut masalah-masalah yang relevan bagi kelompok; (2) saling ketertarikan yaitu ketertarikan dalam bentuk menyukai secara pribadi dan setiap anggota menganggap adanya nilai keuntungan yang diperoleh diantara mereka; (3) solidaritas, yaitu respon secara terkordinasi dalam kelompok di mana tingkahlaku anggota dalam kelompok secara serentak atau berurutan saling memperkuat kelompok. Lebih lanjut Horney dalam
Newcomb, Turner dan Converse (1985) menjelaskan bahwa interaksi sosial secara kompetitif memiliki ciri-ciri sebagai berikut: (1) menarik keuntung dari orang lain yaitu imbalan-imbalan interpersonal yang diterima seseorang dengan cara mendekatai orang lain; (2) tidak bergantung kepada orang lain yaitu sikap yang menganggap diriya realistis dengan mngakui bahwa setiap orang harus mengurus diri sendiri; (3) merasa unggul dari orang lain yaitu sikap bertahan di mana yang paling kuat akan membinasakan yang lemah dengan kebutuhan utamanya menguasai orang lain.

Interaksi sosial koperatif sangat dibutuhkan dalam kegiatan pembelajaran sebab kelas yang demokratis sangat menekankan kepada kecakapan berkerjasama. Pendapat tersebut dikemukan oleh Grambs dalam nasution (2000) bahwa bekerjasama dengan orang lain sangat esensial dalam kehiduan keluarga, dalam peran sebagai warga Negara dan dalam hal pekerjaan. Lie (2002) juga berpendapat kerjasama merupakan kebutuhan yang sangat penting artinya bagi kelangsungan hidup, tanpa bekerjasama tidak akan ada individu, keluarga, organisasi atau sekolah.

Bekerjasama dalam kegiatan pembelajaran wujudnya dilihat pada kerja kelompok. Kerja kelompok ialah cara individu mengadakan relasi dengan individu lain untuk mencapai tujuan bersama (Borton dalam Nasution, 2000). Lebih lanjut Johson dan Johnson dalam Djiwandono (2002) mengatakan bahwa kerjasama adalah paling umum dalam situasi belajar disekolah, bekerja sama menghasilkan perubahan prestasi untuk menjadi lebih koperatif dari persaingan, bekerjasama juga menghasilkan perbaikan kemampuan untuk melihat dunia dari sudut pandang orang lain. Dengan bekerjasama interaksi antar kelompok dapat tercipta sehingga siswa dapat menikmati kegiatan pembajaran.

Sebaliknya interaksi kompetitif sangat diperlukan dalam kegiatan pembelajaran (Nasution, 2000) mengemukakan bahwa, tujuan persaiangan dalam pembelajaran bukan untuk memperoleh hadiah atau kenaikan tingkat, tetapi untuk mencapai hasil yang lebih koperatif atau pemecahan masalah yang dihadapi kelompok, persaingan yang diperbolehkan adalah persaingan dengan tujuan mulia dan tidak ada alasan untuk melarang adanya persaingan sebab dalam pembelajaran demokratis, tidak diharapkan supaya setiap 
siswa memperoleh pengetahuan dan kecekapan yang sama.

Berdasarkan rumusan masalah penelitian, kajian teoretis dan kerangka berpikir, maka hipotesis penelitian ini dapat diajukan sebagai berikut: (1) Hasil belajar Sejarah siswa yang dibelajarkan dengan strategi pembelajaran berbasis masalah lebih tinggi dibandingkan dengan siswa yang dibelajarkan dengan strategi pembelajaran ekspositori; (2) Hasil belajar Sejarah siswa yang memiliki interaksi sosial kompetitif lebih tinggi dibandingkan dengan siswa yang memiliki interaksi sosial koperatif; dan (3) Terdapat interaksi antara strategi pembelajaran dan interaksi sosial terhadap hasil belajar Sejarah siswa.

\section{METODE}

Penelitian ini dilaksanakan di SMA Negeri 1 Padang Tualang dan SMA Negeri 1 Kecamatan Binjai Kabupaten Langkat. Pelaksanaan penelitian diawali dengan melakukan peninjauan ke lokasi penelitian untuk mengetahui secara cermat tentang keadaan jumlah kelas dan siswa kelas XI (sebelas) jurusan IPS yang menerima mata pelajaran Sejarah, latar belakang dan pengalaman guru yang memberikan mata pelajaran Sejarah, sarana belajar, dan kondisi kelas.

Populasi penelitian ini adalah seluruh siswa kelas XI IPS SMA Negeri 1 Padang Tualang dan SMA Negeri 1 Kecamatan Binjai Kabupaten Langkat. Siswa kelas XI jurusan IPS SMA Negeri 1 Padang Tualang dan SMA Negeri 1 Kecamatan Binjai masing-masing memiliki 3 (tiga) kelas. Selanjutnya, setiap kelas berjumlah 40 orang. Jadi, jumlah sampel populasi seluruhnya 6 (enam) kelas dengan jumlah siswa keseluruhan 240 orang.

Sampel merupakan sebahagian dari populasi yang dipilih secara representatif, artinya karakteristik populasi tercermin dalam sampel yang diambil (Sudjana, 1992). Teknik penarikan sampel dalam penelitian ini adalah Cluster Random Sampling. Teknik digunakan, jika dijumpai populasi yang heterogen dimana sub populasi merupakan suatu kelompok (cluster) yang mempunyai sifat yang heterogen (Arikunto, 2003). Cara pengundian dilakukan dengan menulis nama kelas pada kertas yang digulung, dan terpilihlah sebagai kelas eksperimen yang menerapkan strategi pembelajaran berbasis masalah adalah kelas $\mathrm{XI}^{\mathrm{A}}$ SMA Negeri 1 Padang Tualang, dan sebagai kelas eksperimen yang menerapan srategi pembelajaran ekspositori adalah kelas $\mathrm{XI}^{2}$ SMA Negeri 1 Kecamatan Binjai dengan jumlah siswa masing-masing 40 orang. Dengan demikian seluruh subjek penelitian ini adalah 80 orang. Selanjutnya, untuk lebih meyakinkan bahwa kedua kelompok subjek yang dipilih sama, dilakukanlah uji kesamaan dua rerata (mean) uji varian homogenitas Bartlett (Arikunto, 2003).

Data yang diuji adalah data interaksi sosial siswa dari hasil angket (kuisioner). Selanjutnya setelah dilakukan analisis mengenai interaksi sosial, ditentukan 2 (dua) kategori tingkat interaksi sosial, yakni interaksi sosial koperatif, dan kompetitif. Pembelajaran yang sama diterapkan kepada seluruh siswa dengan kedua jenis interaksi sosial siswa tersebut.

Penelitian ini adalah penelitian kuantitatif dengan jenis penelitian kuasi eksperimen disain faktorial 2x2. Melalui disain ini akan dibandingkan pengaruh strategi pembelajaran berbasis masalah dan ekspositori, terhadap hasil belajar Sejarah, ditinjau dari siswa yang memiliki interaksi sosial koperatif dan kompetitif. Strategi pembelajaran berbasis masalah dan ekspositori sebagai variabel bebas dan interaksi sosial koperatif dan kompetitif sebagai variabel moderator. Perolehan hasil belajar Sejarah sebagai variabel terikat. Selanjutnya variabel dimasukkan di dalam disain penelitian sebagaimana Tabel 1 berikut:

Tabel 1. Rancangan Penelitian Untuk Pengujian Hipotesis

\begin{tabular}{|l|c|c|}
\hline \multirow{2}{*}{ Interaksi sosial } & \multicolumn{2}{|c|}{ Strategi Pembelajaran } \\
\cline { 2 - 3 } & $\begin{array}{c}\text { Berbasis Masalah } \\
\left(\mathrm{A}_{1}\right)\end{array}$ & Ekspositori $\left(\mathrm{A}_{2}\right)$ \\
\hline Tinggi $\left(\mathrm{B}_{1}\right)$ & $\left(\mathrm{A}_{1} \mathrm{~B}_{1}\right)$ & $\left(\mathrm{A}_{2} \mathrm{~B}_{1}\right)$ \\
\hline Rendah $\left(\mathrm{B}_{2}\right)$ & $\left(\mathrm{A}_{1} \mathrm{~B}_{2}\right)$ & $\left(\mathrm{A}_{2} \mathrm{~B}_{2}\right)$ \\
\hline
\end{tabular}

Keterangan :

$\mathrm{A}_{1} \mathrm{~B}_{1}=$ Hasil belajar Sejarah siswa yang memiliki interaksi sosial kompetitif dibelajarkan dengan menggunakan strategi pembelajaran berbasis masalah.

$\mathrm{A}_{1} \mathrm{~B}_{2}=$ Hasil belajar Sejarah siswa yang memiliki interaksi sosial koperatif 
dibelajarkan dengan menggunakan strategi pembelajaran berbasis masalah .

$\mathrm{A}_{2} \mathrm{~B}_{1}=$ Hasil belajar Sejarah dari siswa yang memiliki interaksi sosial kompetitif dibelajarkan dengan menggunakan strategi pembelajaran ekspositori.

$\mathrm{A}_{2} \mathrm{~B}_{2}=$ Hasil belajar Sejarah dari siswa yang memiliki interaksi sosial koperatif dibelajarkan dengan menggunakan strategi pembelajaran ekspositori.

Teknik analisis data yang digunakan dalam penelitian ini adalah teknik statistik deskriptif dan inferensial. Teknik statistik deskriptif digunakan untuk mendeskripsikan data, antara lain nilai rata-rata (Mean), Median, Standard Deviasi (sd) dan kecenderungan data. Teknik statistik inferensial digunakan untuk menguji hipotesis penelitian, dengan teknik analisis varians Anava dua jalur (desain factorial $2 \times 2$ ) dengan taraf signifikan $5 \%$ atau 0,05 .

Sebelum Anava dua jalur dilakukan, terlebih dahulu ditentukan persyaratan analisis yakni persyaratan Normalitas menggunakan Uji Liliefors, sedangkan untuk uji persyaratan Homogenitas menggunakan Uji Bartlett dan uji Fisher (Sudjana, 1984). Setelah melakukan pengujian persyaratan analisis, selanjutnya dilakukan pengujian Anava 2 jalur. Anava 2 jalur ternyata signifikan, maka diadakan uji lanjut (post hoc test), menggunakan uji Scheffe', sebab sampel tiap sel tidak sama (n tidak sama).
Adapun hipotesis statistik yang akan diuji adalah:

1. Hipotesis Pertama

Ho $: \mu \mathrm{A}_{1}=\mu \mathrm{A}_{2}$

$\mathrm{Ha}: \mu \mathrm{A}_{1}>\mu \mathrm{A}_{2}$

2. Hipotesis Kedua

Ho : $\mu \mathrm{B}_{1}=\mu \mathrm{B}_{2}$

$\mathrm{Ha}: \mu \mathrm{B}_{1}>\mu \mathrm{B}_{2}$

3. Hipotesis Ketiga

Ho : $\mathrm{A}><\mathrm{B}=0$

$\mathrm{Ha}: \mathrm{A}><\mathrm{B} \neq 0$

\section{Keterangan:}

$\mathrm{A}=$ Strategi pembelajaran

$\mathrm{B}=$ Interaksi sosial siswa

$\mu \mathrm{A}_{1}=$ nilai rata-rata sejarah siswa yang dibelajarkan dengan strategi pembelajaran berbasis masalah.

$\mu \mathrm{A}_{2}=$ nilai rata-rata sejarah siswa yang dibelajarkan dengan strategi pembelajaran ekspositori.

$\mu \mathrm{B}_{1}=$ nilai rata-rata sejarah siswa yang memiliki interaksi sosial kompetitif.

$\mu B_{2}=$ nilai rata-rata sejarah siswa yang memiliki interaksi sosial koperatif.

\section{HASIL DAN PEMBAHASAN}

Berdasarkan data skor tes hasil belajar Sejarah siswa, langkah berikutnya adalah menghitung total skor dan rata-rata skor tiap kelompok perlakuan menurut tabel anava, yang selanjutnya dapat digunakan sebagai dasar keputusan statistik untuk pengujian hipotesis, seperti pada Tabel 2 sebagai berikut :

Tabel 2. Statistik Anava 2 Jalur

\begin{tabular}{|c|c|c|c|c|c|c|}
\hline SP & \multicolumn{2}{|c|}{ Berbasis Masalah } & \multicolumn{2}{|c|}{ Ekspositori } & \multicolumn{2}{|r|}{ Total } \\
\hline $\mathrm{T}$ & $\begin{array}{l}\frac{\mathrm{n}}{\mathrm{X}} \\
\Sigma \mathrm{X} \\
\Sigma \mathrm{X}^{2} \\
\mathrm{Sd} \\
\mathrm{Sd}^{2}\end{array}$ & $\begin{array}{l}=16 \\
=25,19 \\
=403 \\
=10227 \\
=2,26 \\
=5,10\end{array}$ & $\begin{array}{l}\frac{\mathrm{n}}{\mathrm{X}} \\
\Sigma \mathrm{X} \\
\Sigma \mathrm{X}^{2} \\
\mathrm{Sd} \\
\mathrm{Sd}^{2}\end{array}$ & $\begin{array}{l}=22 \\
=21,00 \\
=462 \\
=9762 \\
=1,65 \\
=2,72\end{array}$ & $\begin{array}{l}\frac{\mathrm{N}}{\mathrm{X}} \\
\Sigma \mathrm{X} \\
\Sigma \mathrm{X} \\
\mathrm{Sd} \\
\mathrm{Sd}^{2}\end{array}$ & $\begin{array}{l}=38 \\
=46,19 \\
=865 \\
=19989 \\
=3,88 \\
=3.885\end{array}$ \\
\hline $\mathrm{R}$ & $\begin{array}{l}\frac{\mathrm{n}}{\mathrm{X}} \\
\Sigma \mathrm{X} \\
\Sigma \mathrm{X}^{2} \\
\mathrm{Sd} \\
\mathrm{Sd}^{2}\end{array}$ & $\begin{array}{l}=24 \\
=16,96 \\
=407 \\
=7011 \\
=2,13 \\
=4,53\end{array}$ & $\begin{array}{l}\frac{\mathrm{n}}{\mathrm{X}} \\
\Sigma \mathrm{X} \\
\Sigma \mathrm{X}^{2} \\
\mathrm{Sd} \\
\mathrm{Sd}^{2}\end{array}$ & $\begin{array}{l}=18 \\
=18,78 \\
=338 \\
=6484 \\
=2,75 \\
=7,62\end{array}$ & $\begin{array}{l}\frac{\mathrm{N}}{\mathrm{X}} \\
\Sigma \mathrm{X} \\
\Sigma \mathrm{X} \\
\mathrm{Sd} \\
\mathrm{Sd}^{2}\end{array}$ & $\begin{array}{l}=42 \\
=35,74 \\
=745 \\
=13495 \\
=4,88 \\
=4.045\end{array}$ \\
\hline & & $\begin{array}{l}=40 \\
=42,15 \\
=810\end{array}$ & & $\begin{array}{l}=40 \\
=39,78 \\
=800\end{array}$ & $\frac{\mathrm{N}}{\mathrm{X}}$ & $\begin{array}{l}=80 \\
=81,93 \\
=1610\end{array}$ \\
\hline
\end{tabular}




\begin{tabular}{|l|l|l|l|l|}
\hline Total & $\Sigma \mathrm{X}^{2}=17238$ & $\Sigma \mathrm{X}^{2}=16248$ & $\Sigma \mathrm{X}^{2}=33484$ \\
& $\mathrm{Sd}=4,39$ & $\mathrm{Sd}=4,37$ & $\mathrm{Sd}=8,76$ \\
& $\mathrm{Sd}^{2}=4.815$ & $\mathrm{Sd}^{2}=3.115$ & $\mathrm{Sd}^{2}=7.93$ \\
\hline
\end{tabular}

Secara keseluruhan hasil Anava untuk pengujian hipotesis dapat dilihat pada Tabel 3 di bawah ini.

Tabel 3. Rangkuman Hasil Anava Secara Keseluruhan Terhadap Hasil Belajar Sejarah

\begin{tabular}{|l|c|c|c|c|c|}
\hline Sumber Variasi & JK & $\mathbf{d k}$ & $\mathbf{K T}$ & $\mathbf{F}_{\text {hit }}$ & \multirow{2}{*}{$\mathbf{F}_{\text {tab }}$} \\
\hline Baris & 27,48 & 1 & 27,48 & 5,46 & \\
\cline { 1 - 4 } Kolom & 532,08 & 1 & 532,08 & 105,78 & \\
\cline { 1 - 4 } Interaksi & 175,99 & 1 & 175,99 & 34,99 & \\
\cline { 1 - 5 } Dalam & 382,51 & 76 & 5,03 & & \\
\hline Total & 1117,57 & 79 & & & \\
\hline
\end{tabular}

Perbedaan Hasil Belajar Sejarah antara Siswa yang Memperoleh Strategi Pembelajaran Berbasis Masalah dan Ekspositori. adalah :

Adapun hipotesis statistik yang diuji

\section{Ho $: \mu \mathrm{A} 1=\mu \mathrm{A} 2$}

$\mathrm{Ha}: \mu \mathrm{A} 1>\mu \mathrm{A} 2$

Berdasarkan hasil pengujian hipotesis pada tabel 18 di atas diperoleh $\mathrm{Fc}$ sebesar 105,78. Sementara nilai kritik $\mathrm{F}_{\text {tabel }}$ dengan $\mathrm{dk}=$ $(1,76)$ dan $\propto=5 \%$ adalah sebesar 3,95. Hasil ini menunjukkan bahwa $\mathrm{F}_{\text {hitung }}=105,78>\mathrm{F}_{\text {tabel }}=$ 3,95, sehingga Hipotesis Nol (Ho) ditolak, dengan demikian hipotesis penelitian yang menyatakan bahwa hasil belajar Sejarah siswa yang dibelajarkan dengan strategi pembelajaran berbasis masalah lebih tinggi dari pada strategi pembelajaran ekspositori teruji kebenarannya.

\section{Perbedaan Hasil Belajar Sejarah antara}

Siswa yang Memiliki Interaksi sosial kompetitif Dan Rendah. adalah :

Adapun hipotesis statistik yang diuji

Ho : $\mu \mathrm{B} 1=\mu \mathrm{B} 2$

$\mathrm{Ha}: \mu \mathrm{B} 1>\mu \mathrm{B} 2$

Berdasarkan hasil pengujian hipotesis pada Tabel $17 \mathrm{di}$ atas diperoleh $\mathrm{Fr}=5,46$ dan nilai kritik $\mathrm{F}_{\text {tabel }}$ dengan $\mathrm{dk}=(1,76)$ dan $\propto=5$ $\%$ adalah 3,95. Hasil ini menunjukkan bahwa $\mathrm{F}_{\text {hitung }}=5,46>\mathrm{F}_{\text {tabel. }}=3,95$ sehingga Hipotesis Nol (Ho) ditolak, dengan demikian hipotesis penelitian yang menyatakan bahwa siswa yang memiliki interaksi sosial kompetitif memperoleh hasil belajar Sejarah yang lebih tinggi dari pada siswa yang memiliki interaksi sosial koperatif teruji kebenarannya.

Interaksi antara Strategi Pembelajaran dan Interaksi sosial Siswa dalam Mempengaruhi Hasil Belajar Sejarah Siswa Adapun hipotesis statistik yang diuji adalah :

Ho : $\mathrm{A}><\mathrm{B}=0$

Ha : $\mathrm{A}>\langle\mathrm{B} \neq \mathbf{0}$

Berdasarkan hasil pengujian hipotesis di atas diperoleh $\mathrm{Fr}_{\mathrm{c}}=34,99$ dan nilai kritik $\mathrm{F}_{\text {tabel }}$ dengan $\mathrm{dk}=(1,76)$ dan $\propto=5 \%$ adalah 3,95 . Hasil ini menunjukkan bahwa $F_{\text {hitung }}=34,99>$ $F_{\text {tabel. }}=3,95$ sehingga Hipotesis Nol (Ho) ditolak, dengan demikian hipotesis penelitian yang menyatakan bahwa terdapat interaksi antara strategi pembelajaran dan interaksi sosial dalam mempengaruhi hasil belajar Sejarah teruji kebenarannya.

Karena ada interaksi antara strategi pembelajaran dan Interaksi sosial dalam mempengaruhi hasil belajar Sejarah, maka perlu dilakukan uji lanjutan (post hoc test), untuk mengetahui rata-rata hasil belajar sampel mana yang berbeda. Untuk melihat bentuk interaksi antara strategi pembelajaran dan interaksi sosial dalam mempengaruhi hasil belajar Sejarah, dilakukan uji lanjut dengan menggunakan uji Scheffe', seperti pada Tabel 4 berikut :

Tabel 4. Ringkasan Hasil Perhitungan Uji Scheffe'

\begin{tabular}{|l|l|c|c|c|}
\hline \multicolumn{2}{|c|}{ Hipotesis Statistik } & \multirow{2}{*}{$\mathbf{F}_{\text {hitung }}$} & \multicolumn{2}{c|}{$\mathbf{F}_{\text {table }}$} \\
\cline { 4 - 5 } & $\mathbf{\alpha = 5} \%$ & $\mathbf{A}=\mathbf{1} \%$ \\
\hline Ho: $\mu \mathrm{A}_{1} \mathrm{~B}_{1}=\mu \mathrm{A}_{2} \mathrm{~B}_{1}$ & $\mathbf{H a}: \mu \mathrm{A}_{1} \mathrm{~B}_{1}>\mu \mathrm{A}_{2} \mathrm{~B}_{1}$ & 5,69 & 2,72 & 4,05 \\
\hline Ho: $\mu \mathrm{A}_{1} \mathrm{~B}_{2}=\mu \mathrm{A}_{2} \mathrm{~B}_{2}$ & $\mathbf{H a}: \mu \mathrm{A}_{1} \mathrm{~B}_{2}>\mu \mathrm{A}_{2} \mathrm{~B}_{2}$ & 11,37 & 2,72 & 4,05 \\
\hline
\end{tabular}




\begin{tabular}{|l|l|l|l|l|}
\hline Ho: $\mu \mathrm{A}_{1} \mathrm{~B}_{1}=\mu \mathrm{A}_{1} \mathrm{~B}_{2}$ & $\mathbf{H a}: \mu \mathrm{A}_{1} \mathrm{~B}_{1}>\mu \mathrm{A}_{1} \mathrm{~B}_{2}$ & 7,98 & 2,72 & 4,05 \\
\hline Ho: $\mu \mathrm{A}_{2} \mathrm{~B}_{1}=\mu \mathrm{A}_{2} \mathrm{~B}_{2}$ & $\mathbf{H a}: \mu \mathrm{A}_{2} \mathrm{~B}_{1}>\mu \mathrm{A}_{2} \mathrm{~B}_{2}$ & 4,98 & 2,72 & 4,05 \\
\hline Ho: $\mu \mathrm{A}_{1} \mathrm{~B}_{1}=\mu \mathrm{A}_{2} \mathrm{~B}_{2}$ & $\mathbf{H a}: \mu \mathrm{A}_{1} \mathrm{~B}_{1}>\mu \mathrm{AB}_{2}$ & 6,10 & 2,72 & 4,05 \\
\hline Ho: $\mu \mathrm{A}_{2} \mathrm{~B}_{1}=\mu \mathrm{A}_{1} \mathrm{~B}_{2}$ & $\mathbf{H a}: \mu \mathrm{A}_{2} \mathrm{~B}_{1}>\mu \mathrm{A}_{1} \mathrm{~B}_{2}$ & 4,74 & 2,72 & 4,05 \\
\hline
\end{tabular}

Selanjutnya, adanya interaksi antara variabel strategi pembelajaran dan Interaksi sosial terhadap hasil belajar Sejarah siswa, maka perlu diberikan gambaran grafik adanya interaksi tersebut.

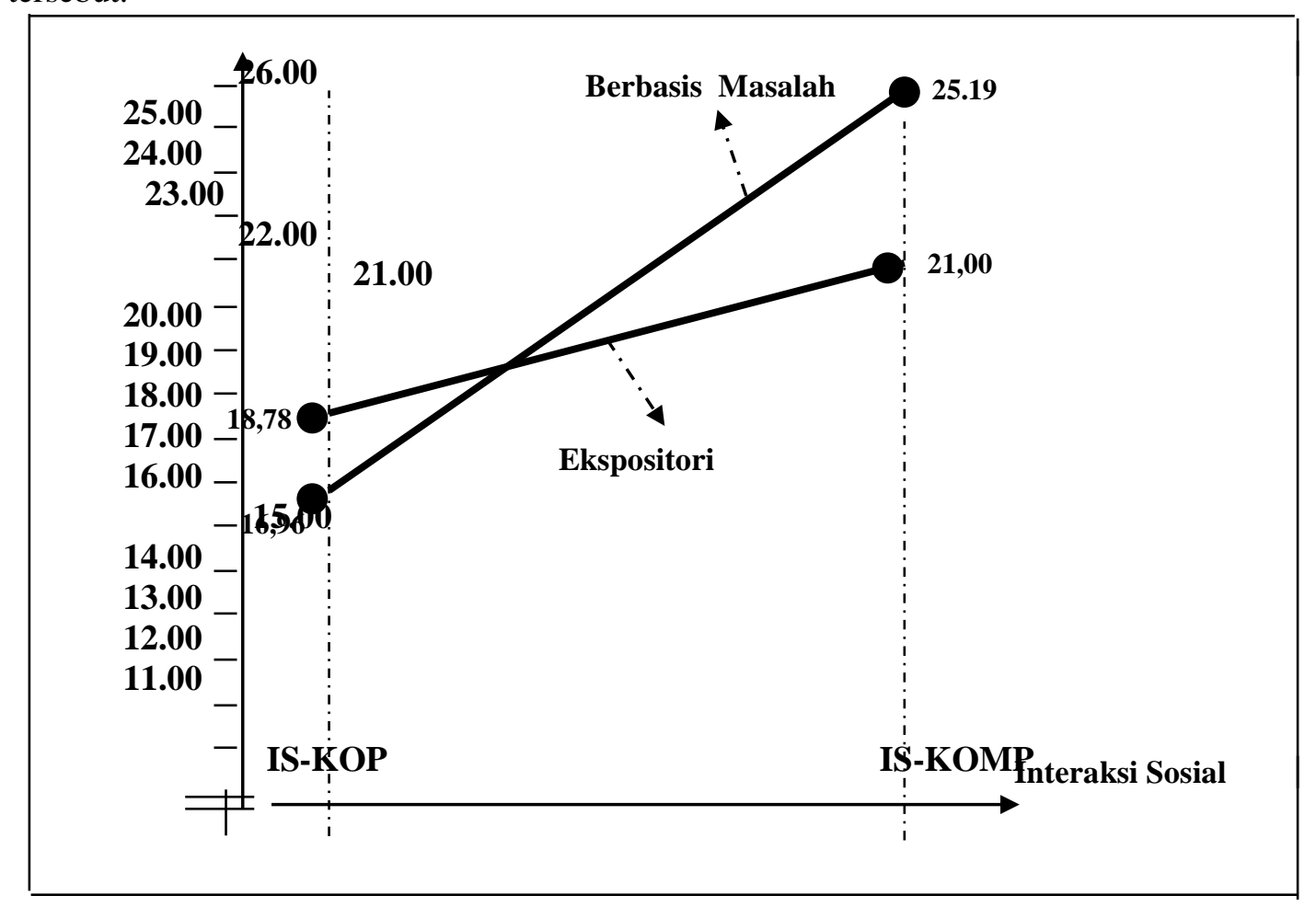

Gambar 1. Interaksi Antara Strategi Pembelajaran dan Interaksi sosial Terhadap Hasil Belajar Sejarah Siswa

\section{PENUTUP}

Hasil belajar Sejarah siswa SMA Negeri 1 Padang Tualang Kabupaten Langkat yang dibelajarkan dengan strategi pembelajaran berbasis masalah lebih tinggi dibandingkan jika diajar dengan menggunakan strategi pembelajaran ekpositori.

Siswa yang memiliki interaksi sosial kompetitif memperoleh hasil belajar Sejarah yang lebih tinggi dibandingkan dengan siswa yang memiliki interaksi sosial koperatif.

Terdapat interaksi antara strategi pembelajaran dan interaksi sosial dalam mempengaruhi hasil belajar Sejarah siswa SMA Negeri 1 Padang Tualang Kabupaten Langkat. Untuk siswa yang memiliki interaksi sosial kompetitif lebih efektif dalam meningkatkan hasil belajar Sejarah siswa menggunakan strategi pembelajaran berbasis masalah dari pada menggunakan strategi pembelajaran ekspositori. Sedangkan untuk siswa yang memiliki interaksi sosial koperatif, ternyata strategi pembelajaran ekspositori lebih efektif dalam meningkatkan hasil belajar Sejarah siswa, dari pada menggunakan strategi pembelajaran berbasis masalah.

\section{DAFTAR PUSTAKA}

Agustanto, B. (2008). Pengaruh Strategi Pembelajaran dan Gaya Kognitif Terhadap Hasil Belajar Biologi SMP Negeri 4 Kecamatan Bahorok. Tesis. Medan : Program Pascasarjana Universitas Negeri Medan.

Atmadi, A. (2000). Transformasi Pendidikan Memasuki Millenium Ketiga. Yogyakarta : Kanisius.

Arikunto, S. (2003). Prosedur Penelitian, Suatu Pendekatan Praktek. Jakarta : Rineka Cipta.

Ary, D. Jacobs, and L.C. Razavieh A. (1992). Pengantar Penelitian Dalam Pendidikan 
(Penerjemah : Purchan, A). Surabaya Nasional.

Balitbang, Depdiknas. (2006). Kurikulum Tingkat Satuan Pendidikan. Jakarta : Pusat Kurikulum Balitbang Depdiknas.

Depdikbud. (2006). KTSP SMA Sejarah Kelas XI. Jakarta : Departemen Pendidikan Nasional

Dick,W dan Carey, L (2006). The Systemathic Design of Instruction. $4^{\text {th }}$. Harper Collins Publishers.

Fernandes, H. J. X., (1985). Testing and Measurement. Jakarta: National Educational Planning Evalution and Currilum Depelovement.

Hamacheck, D. dan Slavin (1990). Phsycology in Teaching Learning and Growth. Toronto : Allyn and Bacon

Heinich, RE. (1996). Instructional Media and Technologies for Learning $5^{\text {th }}$. New Jersey : Enggle Wood Prentice Hall.

Joyce Bruce and Well Marsha. (1986). Model Of Teaching. New Jersey : Prentice Hall. Inc.

Reigeluth, C.M. (1983). Instructional Design Theory and Models. Laurence Erlbaun Associates, New Jersey : Publisher's Hillsdale

Rezeki, R. (2005). Pengaruh Strategi Pembelajaran Kontekstual dan
Kreativitas Terhadap Hasil Belajar Matematika SLTP Kecamatan Stabat. Tesis. PPs Unimed Medan.

Rogers, C (1982). Freedom To Learn for the 80's. Colombus : Charles E. Merrill

Romizowski, A.J. (1981). Designing Instruksional System, New York : Nicholas Publishing.

Sakdiah, H. (2004). Pengaruh Strategi Pembelajaran dan Interaksi Sosial terhadap hasil belajara siswa SMP Negeri 2 Secanggang.Tesis. PPs Unimed : Medan

Sanjaya, W. (2007). Strategi Pembelajaran, Jakarta : Prenada Media Group.

Semiawan, C.R. (1997). Pendekatan Keterampilan Proses Terbimbing. Jakarta : Gramedia Widiasarana Indonesia.

Soewarso. (2000). Cara-cara Penyampaian Pendidikan Sejarah Untuk Membangkitkan Minat Peserta Didik Mempelajari Bangsanya. DEPDIKNAS

Somantri, N.M. (2001), Menggagas Pembahafuan Pendidikan IPS. Bandung : PT. Remaja Rosdakarya.

Susilawaty, E. (2006). Pengaruh Strategi Pembelajaran dan Interaksi Sosial Terhadap Hasil Belajar PKn Siswa SMP Negeri 5 Tanjungbalai. Tesis. Medan: Pascasarjana Universitas Negeri Medan 